\title{
Impact of Cyber Atmospherics on Buyers of Different E-retailing Sites: Literature Review and Conceptual Model Proposal
}

\author{
Sourabh Bhattacharya
}

Full Time Research Scholar, Faculty of Management Sciences, Siksha O Anusandhan University Bhubaneswar, Odisha,India; sourabhb82@yahoo.com

\section{Dr. Bibhuti Bhusan Mishra}

Assistant Professor, Faculty of Management Sciences, Siksha O Anusandhan University, Bhubaneswar Odisha, India; bibhutibhusanmishra@soauniversity.ac.in

\section{Dr. Uma Sankar Mishra}

Associate Professor, Faculty of Management Sciences, Siksha 'O' Anusandhan University Bhubaneswar Odisha, India; umasankarmishra@soauniversity.ac.in

Doi:10.5901/mjss.2015.v6n6p260

\section{Abstract}

\begin{abstract}
The boom in internet usage coupled with development of required infrastructure and use of different net devices have brought a sea change in the world of retail. Today's net savvy customers are ready both technologically and mentally to take full advantage of these changes. Different categories right from apparel to gifts, accessories, even groceries are now getting sold through the online channel. In order to provide a great shopping experience to the customers e-retailers have taken the path of creating a superb online atmospherics so as to retain the loyalty of customers. Researchers have divided online or cyber atmospherics into six variables. Now the time has come for people both in academics and e-retail industry to gauge the impact of cyber atmospherics on consumers and how it impacts consumer contentment, consumer reliance and consumer adhesion. With the main objective of studying the complicated relationship between elements of cyber atmospherics, consumer behavior and response in terms of contentment, reliance and adhesion this study will propose an integrative Cyber Atmospherics Contentment - Reliance - Adhesion model by putting emphasis on extensive review of literature. The paper has delved extensively into literature to get all of the constructs of the model and validate them.
\end{abstract}

Keywords: Cyber Atmospherics, Consumer Contentment, Consumer Reliance, Consumer Adhesion.

\section{Introduction}

The electronic retail stores are places of creating excitement for the customers. E-Retail industry being in the services sector has to present a great experience for the customers. Retailers have realized that when everything are the same across formats in terms of brands, options, VM, store design the only weapon of differentiation lies in the hands of eretailers is cyber atmospherics. Customer currently is not the king but the God. They can create giants like Amazon.com or E-bay out of their patronage. They can also kill giants like K-Mart, or injure giants like Sainsburry, Marks and Spencer simply by changing their favor to another retailer. So when products are same, vendors are providing the same deals to all the retailers, more and more stores are coming, cyber atmospherics only is acting as the most powerful weapon in the hands of the e-retailers to combat the competition. Even though most of the e-retailers are facing huge amount of losses and are under pressure from their venture capitalist investors, still they are investing billions of dollars in having the right cyber atmospherics.

The obvious question which may arise in this regard is what is cyber atmospherics. The word atmospherics can be traced back to few decades. It first started in offline retailing. Retailers tried to create a superb atmosphere/environment in their stores so as to induce the consumer to spend more time and money which in turn lead to more profitability. All consumers have five senses. So, retailers have resorted to sound/music for soothing the ears of consumers. In this regard hypermarkets resort to fast music whereas departmental stores take the help of soft music. An ice-cream store like Baskin Robbins has used smell very efficiently to compel the consumers to purchase its products. Cosmetics 
companies like Loreal have long used the techniques of free facial to compel the consumers for touch and smell related feelings. This also led to more sales. Retailers also use lights to create great atmospherics. Stores use yellow lights in case of gold ornaments and white lights in case of silver/platinum ornaments. Again fragrance brands like Tommy Hilfiger, Hugo Boss use simple but effective techniques so as to sell their costly products. For example before showing the products, the salesmen put a jar full of coffee beans before the buyers to take a smell. The strong smell of coffee beans put off the presence of any influencing agent in the nasal channel of consumers. Then with the help of special paper stripes the consumers are asked to smell the fragrances. Retail formats like department stores use a combination of all the above mentioned atmospheric techniques to create a superb internal atmospherics in the store.

Cyber atmospherics is nothing but the implementation of offline atmospherics model in online or virtual space. Through cyber atmospherics retailers use color, design, sound to create an inducing environment in the online store. Retailers are experimenting to provide smell of products to the consumers through the use of special computer nodes. Retailers also use avatars, virtual trial rooms, drones in their path to creation of cyber atmospherics. Experiments are being conducted about the impact of different types of colors on consumers.

With the help of cyber atmospherics e-retailers strive to give a superb experience to the customers, that experience, which acts as a magnet for the customers to come back again and again to the e-store.

Let us get into some of the ways through which electronic retailers are creating cyber atmospherics for their consumers:

a. Companies like Myntra, Jabong,Tommy Hilfiger are investing big amount of money to let the customers to smell fragrances.

b. Social Media is being used more and more to engage the customers more with the brand.

c. Companies are resorting to mobile medium to engage more and more with the customers.

d. Companies like Amazon,E-Bay,Wal-Mart are experimenting with colors and music to enthuse the customers in purchasing products.

e. Companies like Flipkart are making shifts in their business models from inventory led model to market place model.

f. E-Retail companies, like the different group companies of Flipkart are establishing service centers to provide the right after-sales services to customers at the right time.

g. E-Retail companies like SnapDeal. YepMe, Jabong are developing hi-tech shopping robots for proper search of products as per price, color, design, style, brand etc.

h. E-Retail companies are developing better and better algorithms to enable more productive searches not only in the shopping site but also in the entire World Wide Web so as to keep the customer satisfied.

i. E-Retail Companies are investing billions of dollars to develop superb logistical infrastructure both forward logistics and reverse logistics.

j. 360 degree communication with the customers through mail, sms, telecalling, social media.

k. Fashion electronic retailing companies first take their products to customers for free trial. If the products fit with the customer then only the final transaction takes place.

I. Amazon's Subscribe and Save policy which helps the customers to take their daily needed products at fixed quantities after fixed intervals.

This paper discusses the significance of cyber atmospherics in influencing consumer behavior in the electronic retailing scenario. Through extensive literature review it demonstrates how the different elements of cyber atmospherics impact consumer behavior and lead to consumer contentment, consumer reliance and consumer adhesion.

\section{Literature Review}

A great amount of time is spent by retailers with the focus to attract customers, relationship building and making customers to purchase products and services (Babin \& Darden, 1996). Today's consumers are very informed and expect the best services. As a result any act from the side of the retailer is bound to have an impact on the relationship with the customers. In this case the ambience of the store which consists of lighting, smell, sound plays as a crucial factor to create a great exciting impact on the customers. Formats especially the department stores spend a great deal of time, energy and money to provide an exciting and engaging environment to the customers (Emmet, 1930). Importance of store environment for customers got pointed out in another study (Kozinets et al., 2002). The stream of study which assesses the importance of connection between store environment and sales is called atmospherics. Its also include the different permutations and combinations with regard to space management carried out by retailers to influence customers towards purchase. Atmospherics creates an impact on emotion which in turn pushes the customers towards purchase 
and repeat purchase of products and services in the retail store (Donovan \& Rossiter, 1982). A conducive and strong atmospherics compels the customers in spending higher time in his/her buying process. Cyber Atmospherics is the application of atmospheric variables in the world of electronic retailing to put an impact on consumers. Cyber atmospherics consists of different variables (Donovan \& Rossiter, 1982; Havlena \& Holbrook, 1996). P-A-D or PleasureArousal-Dominance forms the basis of Cyber Atmospherics. P-A-D deals with the reaction of individuals towards environmental stimuli. This reaction towards environment makes the customer to decide whether to spend more time in the store or not (Bennett, 2005).

Web store atmospherics or cyber atmospherics significantly affect shopper's behavior towards purchase of products and services (Dailey, 2004). Webstore navigation acts as an entertaining factor for customers (Vrechopoulos et al., 2002). Bitner (1996) in his study showed that there exists a connection between 'service-scapes' and approach behavior. Website quality and shopper's behavioral intentions have a strong and positive correlation with relation to information search or price comparison (Lynch \& Ariely,2000). One study concluded that visitor's exploratory behavior in the site is positively related to navigational characteristics of the website (Richard, 2005). A national survey in USA pointed out to 128 variations in shopping experience with regard to different products (Burke, 2002), considering both offline and online retailing. The variations include such aspects like product information, checkout and payment, order fulfillment etc.

\section{Proposed Conceptual Model}

Researchers have carved out totally forty two variables to analyze web content of electronic sites, discount stores, department stores, specialty stores. The variables can be divided into layout and design, external variables, social dimension, customer service, point of purchase(POP), ,interior variables (Mckinney,2004; Kervenoael et al.,2008;Turley \& Milliman, 2000). Those links which are put in the homepages of web shopping sites like corporate information, brands, department listings are called external variables. Again, those links through which, consumers can access particular departments (like Mens, Ladies, Kids) or brands (like Van Heusen or Gas) within the website or electronic store are called internal variables. Informativeness, the second aspect denotes the depth of information and the procedure through which consumers evaluate an electronic store (Chen \& Wells,1999). The third variable is related to the ambience and design variables which represents the overall appearance of the store. Consumers consider issues related to personalization, personal attention to be very important in their online shopping((Brown et al,1993). Again, in this age of social media, social interactivity is a crucial area which can't be ignored by any electronic retailer(Ariely,2000;Klein,2003;Steur,1992; Kervenoael et al.,2008). Finally it also need to be mentioned over here that Hou (2005) in his study tried to connect different elements of service quality with consumer behavior namely customer satisfaction, customer trust and customer loyalty. Based on the above discussion Figure 1 below shows our integrative Cyber Atmospherics - Contentment Reliance - Adhesion model. Description of each construct are given below:

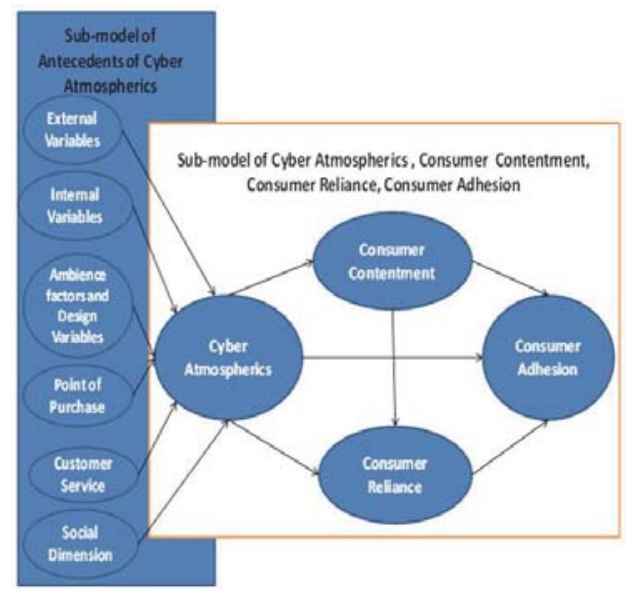

Figure 1: The Conceptual Research Model of Cyber Atmospherics, Consumer Contentment, Consumer Reliance and Consumer Adhesion. 
Based on the above model we can construct the below hypothesis in two parts;

Part I: Hypothesis with regard to the connection between elements of cyber atmospherics and consumer's idea of cyber atmospherics applied by electronic retailers

In relation to electronic retailing

G1a External Variables are a vital element of consumer's understanding of cyber atmospherics.

G1b Internal Variables are a vital element of consumer's understanding of cyber atmospherics.

G1c Ambience Factor and Design Variables are a vital element of consumer's understanding of cyber atmospherics.

G1d Point of Purchase is a vital element of consumer's understanding of cyber atmospherics.

G1e Customer Service is a vital element of consumer's understanding of cyber atmospherics.

G1f Social Dimension is a vital element of consumer's understanding of cyber atmospherics.

Part II: Hypothesis with regard to the connection between Cyber Atmospherics, Consumer Reliance, Consumer Contentment, Consumer Adhesion

In relation to electronic retailing

G2a Consumer's understanding of cyber atmospherics has an affirmative and absolute impact on consumer reliance.

G2b Consumer's understanding of cyber atmospherics has an affirmative and absolute impact on consumer contentment.

G2C Consumer's understanding of cyber atmospherics has an affirmative and absolute impact on consumer adhesion.

G2d Consumer's understanding of cyber atmospherics has an affirmative but no absolute impact on consumer adhesion mediated by consumer contentment and consumer reliance.

G2e Consumer contentment has an affirmative and absolute impact on consumer reliance.

G2f Consumer contentment has an affirmative and absolute impact on consumer adhesion.

G2g Consumer contentment has an affirmative but no absolute impact on consumer adhesion mediated by consumer reliance.

G2h Consumer reliance has an affirmative and absolute impact on consumer adhesion.

\subsection{Cyber Atmospherics}

From the studies of Mckinney(2004) and Kervenoael et al.,(2008), we are considering the below variables directly in our proposed model.

External variables: Links put in the homepage of electronic retailing sites

Facility of subscription to mail based product promotions; Facility of connection with partners and presence of information related to privacy, security and return; Facility of locating offline stores, store map; Listing based on brands, departments; Provision of good promotions, offers ,coupons and loyalty management, Facility of bookmarking the webpage of the electronic retailer; Presence of satisfactory customer service.

Internal variables: Links through which consumers can access particular departments, brands, sizes etc

Facility to shop based on merchandise, brand, special sizes; Provision of proper product knowledge; Charts related to size; Facility of list of best selling and upcoming products, new arrivals,; Checking out of products simultaneously being checked by a number of customers at the same time; Understanding customer needs.

Ambience factors and design variables: The design aspects of the electronic retailer

Scheme, color, photos, snaps used for description by the electronic retailer; Font of the text; Allocation of space; Information placement at the right space.

Point of purchase(POP): Links through which monetary transactions can be carried out

Pricing of products and servicing; Mode of payment; Cost of purchased merchandise within budget; Option of deleting previously selected product or merchandise; Additional purchase suggestions whether provided or not.

Customer service: Links related to value added services

Provision of tollfree customer care number, express checkouts, gift decoration option; Whether shipping can be done to other addresses; Saving option to purchase later; Facility of order confirmation through email; Provision of catalogue requisition; Provision of shipping facilities based on customer's choice, suggestions for gifting; Facility of storing personal information, payment through gift vouchers.

Social dimension: Links for consumers to share views and feedback

Facilities for chatting, mailing and getting product related News; Provision of frequently asked questions; Whether 
its easy to use the site; Pace of loading; Presence of avatars.

\subsection{Consumer Reliance}

Generally consumer reliance can be defined as the intention of trusting a party with whom some transactions or exchanges will take place. The intention also consists of the hope by the buyer that his concerns will be taken care by the seller in case of an exigency(Moorman et al., 1992). In case of breach of trust action can be taken against the seller (Mayer et al., 1995). A number of researchers (Ganesan \& Hess, 1997) have regarded integrity and compassion as the most crucial factors of consumer reliance in an online setting.

Consumer trust model is built up on factors like reliability of the online shopper, reliability of the medium of shopping, trustworthiness of certifications by third parties, scale of company and demographics (Lee \& Turban, 2001).

Its to be mentioned over here that a trust typology consists of four groups of constructs: institution related trust, trust disposition; trust, intentions related to trusting and beliefs (McKnight \& Chervany, 1998).A person's tendency with regard to consistent reliance on another party is called disposition to trust. As it's a part of the characteristics of a person it has a crucial impact on a person's trust related behavior in case of the happening of unfavorable situations (Johnson \& Swap, 1982).

\subsection{Consumer Contentment}

For a long time consumer contentment has been considered as a crucial aspect of consumer behavior (Oliver,1980).A lot of research has been carried out with regard to consumer contentment in brick and mortar or big box retailing (for example, Cronin \& Taylor,1992; Anderson \& Fornell,2012; Zeithaml et al., 1996).

From a traditional point of view, contentment or satisfaction is a mental state through which consumer evaluates whether a product or service is meeting his expectations or not(Zeithaml et al., 1996). Satisfaction or Contentment can also be defined as "the central mediator of post purchase behavior, linking pre-choice product beliefs to post-choice cognitive structure, consumer communications, and repurchase behavior" (Westbrook,1987).

A number of studies describe satisfaction as an affective state of mind with regard to consumer's emotional reaction towards experience of searching in the webstore (Oliver, 1980; Mckinney et al., 2002).

Consumer contentment can be also defined by emphasizing on two levels of aggregation. At the first level it can be defined as an emotional reaction towards a subdued experience. At the second level it also means the overall satisfaction or dissatisfaction based on previous interactions with the electronic retailer (for example, Bitner \& Hubbert, 2012; Rust \& Oliver, 2012 ). In the same context, You(1990) described contentment as a process or an outcome.

\subsection{Consumer Adhesion}

Loyal consumers are always considered as assets in services sector. Research has proved that it costs much more in acquiring a new consumer rather than retaining an old consumer. Loyal consumers always lead to repeat purchase, more profit, positive word of mouth, less immunity to the marketing tactics of competitors and sometimes they are also willing to spend more (Reichheld \& Sasser, 1990).

With regard to adhesion researchers have drawn conclusion about consumer's willingness in providing favor to a business. The attitudinal factors of adhesion has been described in various ways such as consideration of the seller as the first choice (Gremler \& Brown,1996; Javalgi,1997) while going to purchase a product or service, intention to recommend(Javalgi,1997)and emotional attachment to a company, product or brand(Fournier,1998). In this regard commitment (Day, 1969) and positive word of mouth(van \& Semejin,2003) have emerged as the most powerful motivators of repeat purchase by consumers. Its to be mentioned, that recently another new dimension has emerged in the form of cognitive loyalty. It means the minute analysis of assessment of the advantages or rewards of patronizing a brand, product or seller (Gremler \& Brown, 1996) which acts as an important motivator for the consumer in considering an electronic retailer (Dwyer et al., 1987).

\section{Conclusion}

Electronic retailing is a booming field in India. Venture Capitalists from round the world are pouring billions of dollars in it. Some of the biggest names in global electronic retailing industry like Amazon, E-bay, Alibaba are already in the field. Consumers are getting spoilt for choices. All of the electronic retailers are spending VC money in providing the best deals 
to consumers. In order to survive in this cut throat competitive industry, e-retailers are emphasizing on the satisfaction of consumers. Indian consumers at the present moment are searching for the best deals in terms of discounts. When all of the players are providing deals in terms of discounts it becomes evident to retain the consumers not only in terms of deals but also in terms of something else. Cyber atmospherics has emerged as that something else. This paper has discussed extensively the different antecedents of cyber atmospherics and how it is related to consumer behavior. The paper has also proposed a model to relate cyber atmospherics with consumer behavior in terms of consumer contentment, consumer reliance and consumer adhesion. The model can help electronic retailers in a big way in providing the best services to their consumers. The antecedent factors of cyber atmospherics will lead online retailers to create a superb and conducive online atmospherics which will further satisfy the consumers, build their trust and loyalty towards the site. The model in this study has provided a path to electronic retailers which can help them in taking proper strategies. From an overall point of view just like offline atmospherics, online atmospherics also play a very significant role and retailers must dedicate a lot of thought process for it. Keeping in mind of the impact of cyber atmospherics on consumers the content of the site must be designed by electronic retailers so as to provide a long term delight to the consumers.

\section{References}

Anderson, E. \& Fornell, C.(2012). A Customer Satisfaction Research Prospectus. Sage Publications Inc. Retrieved from http://knowledge.sagepub.com/view/service-quality/n11.xml.

Ariely, D. (2000). Controlling the Information Flow: Effects on Consumers' Decision Making and Preferences. Journal of Consumer Research, 26(2), 233-248.

Babin, B., \& Darden, W.(1996). Good and bad shopping vibes: Spending and patronage satisfaction. Journal of Business Research, 35 (3), 201-206.

Bennett, R. (2005). Antecedents and consequences of website atmosphere in online charity fundraising situations. Journal of Website Promotions, 1(1), 131-150.

Bitner, M.(1996). Service scapes: the impact of physical surroundings on employee Responses. Journal of Marketing, 56 (2),57-71.

Bitner, M. \& Hubbert, A.(2012). Encounter Satisfaction versus Overall Satisfaction versus Quality: The Customer's Voice. Sage: Publications Inc. Retrieved from http://knowledge.sagepub.com/view/service-quality/n3.xml.

Brown, T., Churchill,G., \& Peter,J.(1993). Improving the measurement of service quality. Journal of Retailing,69(1),127-139.

Burke, R.(2002) Technology and customer interface: What consumers want in the physical and virtual store. Journal of the Academy of Marketing Science, 30(4), $411-432$.

Chen, Q., \& Wells, W.(1999). Attitude toward the Site. Journal of Advertising Research, 39 (5), 27-37.

Cronin, J., \& Taylor, S. (1992). Measuring service quality: A re-examination and extension. Journal of Marketing, 55(3),56-68.

Dailey, L. (2004). Navigational Web Atmospherics: Explaining the Influence of Restrictive Navigation Cues. Journal of Business Research, 57(7), $795-803$.

Day, G.(1969) .A two-dimensional concept of brand loyalty. Journal of Advertising Research. 9(3), 29-36.

Donovan, R., \& Rossiter, J. (1982). Store atmosphere: An Environmental Psychology approach. Journal of Retailing, 58(1), 34-57.

Dwyer, F., Shurr, P., \& Oh, S. (1987). Developing buyer and seller relationships. Journal of Marketing, 51(2), 11-27.

Emmet, B.(1930). Department stores: recent policies, costs and profits. Retrieved from http://www.sup.org/.

Fournier, S.(1998). Consumers and their brands: Developing relationship theory in consumer research. Journal of Consumer Research. 25(2), $100-120$.

Ganesan, S., \& Hess, R.(1997). Dimensions and levels of trust: Implications for commitment to a relationship. Marketing Letters, 5(4), $439-448$.

Gremler, D. \& Brown, S. (1996). Service loyalty: Its nature, importance, and implications. In B. Brown, S. Johnston, R. Scheuing (Eds.). Advancing Service Quality: A Global Perspective (pp.171-184). International Service Quality Association.

Havlena, W., \& Holbrook, M.(1986). The varieties of consumption experience: Comparing two typologies of emotion in consumer behavior. Journal of Consumer Research, 13(3), 394-404.

Hou,Y.(2005). Service Quality of Online Apparel Retailers And Its Impact on Customer Satisfaction,Customer Trust and Customer Loyalty. Retrieved from www.unc.edu.

Javalgi, R. (1997). Service loyalty: Implications for service providers. Journal of Services Marketing, 11(3), 165-179.

Johnson-George, C., \&Swap, W. (1982). Measurement of specific interpersonal trust: Construction and validation of a scale to assess trust in a specific other. Journal of Personality and Social Psychology, 43(3), 1306-1317.

Kervenoael, R., Aykac, D., \& Bisson, C.(2008,January).The influence of social E-Atmospherics in practice: A website content analysis perspective.In Jean-Claude ANDREANI(Chair), $7^{\text {th }}$ International Congress, Marketing Trend. Conference conducted at Venice, Italy.

Klein,L.(2003). Creating Virtual Product Experiences: The Role of Telepresence. Journal of Interactive Marketing,17(1),41-55.

Kozinets, R., Sherry, J., DeBerry, B. Duhachek,A., Nuttavuthisit, K., \& Storm, D.(2002). Themed Flagship brand stores in the new millennium: theory, practice, prospects. Journal of Retailing, spring, 78(1), 17-29. 
Lee, M., \& Turban,E.(2001). A trust model for consumer Internet shopping. Journal of Electronic Commerce,6(1),75-91.

Lynch, J., \& Ariely, D.(2000).Wine online: Search costs affect competition on price, quality and Distribution. Marketing Science, 19(1), 83-103.

Mayer, R., Davis, J., \& Schoorman, F.(1995). An integrative model of organizational trust. Academy of Management Review,20 (3),709734.

McKinney, N.(2004). Creating a satisfying internet shopping experience via atmospheric variables. International Journal of Consumer Studies,28 (3),268-283.

McKinney, V., Yoon, K., \& Zahedi, F.(2002). The measurement of web-customer satisfaction: An expectation and disconfirmation approach. Information Systems Research, 13 (3), 296-315.

McKnight, D., \& Chervany, N.(1998). Types of Trust - Contrasting Theories. Information Colloquium conducted at of the Department of Information and Management Sciences, Florida State University, Tallahassee, USA.

Moorman,C.,Zaltman, G., \& Deshpande,R.(1992). Relationships between providers and users of market research: The dynamics of trust within and between organizations. Journal of Marketing Research,29(3),314-328.

Oliver, R.(1980). A cognitive model of the antecedents and consequences of satisfaction Decisions. Journal of Marketing Research.17 (4), 460-469.

Reichheld, F., \& Sasser, W.(1990). Zero defections: Quality comes to services. Harvard Business Review. 6S: 105-111.

Richard, M.(2005). Modeling the impact of internet atmospherics on surfer behaviour. Journal of Business Research, 58(12), 1632-1642.

Rust, R., \& Oliver, R.(2012).Service quality: Insights and managerial implications from the frontier. Sage Publications Inc; Retrieved from: http://knowledge.sagepub.com/view/service- quality/n11.xml.

Steur,J.(1992). Defining Virtual Reality: Dimensions Determining Telepresence. Journal of Communication, 42(4), 73-93.

Turley, L., \& Milliman, R.(2000). Atmospheric Effects on Shopping Behavior: A Review of the Experimental Evidence. Journal of Business Research, 49 (2), 193-211.

Van, R., \& Semejin, J.(2003). Online travel service quality: Towards delight and loyal Customers. Retrieved from http://www.ou.nl/Docs/ Faculteiten/MW/MW\%20Working\%20Papers/GR03-05.pdf

Vrechopoulos, A., Papamichail, G., \& Doukidis,G.(2002). Identifying patterns in internet retail store layouts. In. Pardalos, Panos, Tsitsiringos, Vassilis(Eds). Financial Engineering, E-commerce and Supply Chain (pp 231 - 245). Dordrecht. Kluwer Academic Publishers.

Westbrook, R. (1987). Product/consumption-based affective responses and post purchase processes. Journal of Marketing Research. 24(4),258-270.

You, Yi. (1990). A critical review of consumer satisfaction. Review of Marketing Research, 4 (1), 68 - 123.

Zeithaml, V., Berry, L., \& Parasuraman, A. (1996).The behavioral consequences of service quality. Journal of Marketing,60(2),31-46. 